\section{2,3-Dihydroxynaphthalene as Indicator for the Complexometric Titration of Iron(III) with EDTA}

2,3-Dihydroxynaphthalin als Indicator für die komplexometrische Titration von Eisen(III) mit ÄDTA

Best. von Eisen(III); Volumetrie; ÄDTA-Titration, 2,3-Dihydroxynaphthalin als Indicator.

Gurcharan Singh Manku

Hans Raj College, Delhi 110007, India

Received September 23, 1972

The present note describes the use of 2,3-dihydroxynaphthalene as a metal indicator for the complexometric titration of iron(III) with EDTA. The optimum conditions worked out are incorporated in the following procedure.

Adjust the $\mathrm{pH}$ of the acidic iron(III) solution containing 0.1 to $67.0 \mathrm{mg}$ of iron(III) to about 2 with ammonia, add $10 \mathrm{ml}$ of $1 \mathrm{M}$ hydrochloric acid-sodium acetate buffer $\mathrm{pH} 5$ (optimum range for the titration is $4.85-5.65$ ) and $5-10$ drops of $0.5 \% \mathrm{w} / \mathrm{v}$ ethanolic solution of 2,3-dihydroxynaphthalene, dilute to about $100 \mathrm{ml}$ with distilled water and titrate against 0.010 to $0.050 \mathrm{M}$ EDTA solution till a sharp colour change from purple to colourless is observed.

With higher amounts of iron(III), the end point is indicated by the disappearence of last traces of the purple colour leaving a clear yellow solution.

The relative standard deviation for the titration has been found to be in the range $0.8-1.5 \%$.

The colour of the iron(III)-2,3-dihydroxynaphthalene complex is royal blue at $\mathrm{pH} 1-3$, purple at

\section{Microdetermination of Formic, Oxalic and Acetic Acids in Their Mixture by Selective Oxidation}

Mikrobestimmung von Ameisen-, Oxal- und Essigsäure im Gemisch durch selektive Oxidation

Mikrobest. von Ameisensäure; Oxalsäure; Essigsäure im Gemisch, selektive Oxidation mit $\mathrm{Ag}$ (III) und $\mathrm{Cu}(\mathrm{III})$.

\section{P. K. Jaiswal}

Chemical Laboratories Allahabad University, Allahabad, India

Received May 12, 1972

In the present paper, formic, oxalic and acetic acids have been determined in their mixture by selective oxidation with $\mathrm{Ag}$ (III) and $\mathrm{Cu}$ (III) reagents (see also our earlier publication on oxalic, formic and tartaric acids [2]).
$\mathrm{pH}$ 4-6, and red above $\mathrm{pH} 7$. As the titrations were found to be possible only in the range $4.85-5.65$, end point was taken to be the disappearance of the purple colour.

With very large concentrations of iron(III) ( $80 \mathrm{mg}$ and above), titrations became erratic probably because of the larger concentrations of acetate ions required to keep iron(III) in solution.

Interferences. The following ions do not cause any interference even when present in quantities up to 100 times that of iron: bromide, borate, tartrate, citrate, fluoride, zinc, cadmium, calcium, barium, strontium, manganese(II), magnesium and beryllium.

The following ions can be tolerated in the amounts given in the parentheses, together with the masking agent if any, for $5.85 \mathrm{mg}$ of iron(III) : aluminium(III) (100 mg, citrate), antimony(III) (50 mg, tartrate), bismuth(III) $(50 \mathrm{mg}$, tartrate or thiourea with end point as disappearance of traces of purple colour), cobalt(II) (50 mg, tartrate), zirconium(IV) (100 mg; tartrate, citrate), titanium(IV) (10 mg, tartrate), phosphate $(50 \mathrm{mg})$, thiosulphate $(100 \mathrm{mg})$ and iodide (50 mg, thiosulphate).

The following ions interfere seriously: cyanide, sulphocyanide, oxalate, nickel(II), vanadium(IV), vanadate, molybdate, tungstate, uranyl and copper(II).

\section{Dr. G. S. Manku}

Hans Raj College

Delhi 110007

India

$\mathrm{Ag}$ (III) oxidises only formic acid under specific conditions. Diperiodato cuprate(III) solution oxidises only formic and oxalic acids under verified conditions, whereas ditellurato cuprate(III) solution oxidises formic, oxalic as well as acetic acids. Thus by the use of these three oxidants we can determine the three acids separately in their mixture.

\section{Materials}

Ditellurato Argentate(III) and Ditellurato Cuprate(III) Solutions were prepared and standardised as described earlier [3 and 1, resp.].

Diperiodato Cuprate(III) Solution. Copper sulphate $(3.54 \mathrm{~g})$, potassium periodate $(6.80 \mathrm{~g})$, potassium persul. phate $(2.20 \mathrm{~g})$ and potassium hydroxide $(9.00 \mathrm{~g})$ were added to $250 \mathrm{ml}$ of water. The mixture was shaken thoroughly and then heated on a hot plate for about quarter to one hour. The mixture is then cooled and filtered through a sintered glass crucible (porosity 4) and the clear filtrate is 